\title{
A Study on the Influence of Word of Mouth Communication in the Facebook Audience of Restaurants
}

\author{
Maria Christina Lima Nunes ${ }^{1} \&$ Rafael Lucian ${ }^{1}$ \\ ${ }^{1}$ Mestrado Profissional em Gestão Empresarial / Faculdade Boa Viagem - DeVry, Brasil \\ Correspondence: Rafael Lucian, Mestrado Profissional em Gestão Empresarial / Faculdade Boa Viagem - DeVry \\ Brasil. E-mail: rlucian@fbv.edu.br
}

Received: August 29, 2014

Accepted: September 22, 2014

Online Published: October 25, 2014

doi:10.5539/ibr.v7n11p1

URL: http://dx.doi.org/10.5539/ibr.v7n11p1

\begin{abstract}
The expansion of Facebook as a social network, which aggregates countless individuals and companies, makes it a potential tool in the promotion of products and services. In this context, this research seeks to understand how word of mouth communication in a virtual platform using Facebook can be an influence in attracting new communicators. The Dali Cocina restaurant represented the experiment reference. The methodology included a descriptive phase and an experimental analysis. The first questionnaire was administered to 150 users simultaneously frequenting Facebook and restaurants. Next, the experimental phase of work took place, where 12 random guests who worked on the initial message emission through the Facebook tool participated. From there, the following parameters were monitored: the number of followers, their interactions and views of the restaurant's Fanpage. The results confirm that the word of mouth communication through the Facebook platform is an excellent tool for disclosure in the company studied, Dali Cocina.
\end{abstract}

Keywords: marketing, word of mouth communication, social networks, Facebook, restaurant

\section{Introduction}

The act of consumption is an essential practice of the entire capitalist society and consists of the need to acquire goods or services for enjoyment. There is a need to consume from basic commodities to those considered luxurious. Their choice varies with each individual, being influenced by their knowledge, attitude, motivation, personality, values and available resources (Engel; Miniard \& Blackwell, 2000; Gresolle, 2008). It is configured here the first thematic delimitation of this research, which targets the consumer who buys for himself.

Buying a product or good occurs rationally when individuals buy what is needed, paying an acceptable value for it. In this approach, the business transaction is carried out after detailed analysis of the benefits of the product, taking into consideration its quality, performance, durability and price, among others. The rational purchase is generally associated with the acquisition of high value assets like real estate. There is another type of purchase, motivated by emotion, by impulse. Here there is not always a real need of the product, which ends up being acquired by the emotional appeal it has on the individual (Kotler, 1998).

There are several marketing strategies applied in order to highlight the product and attract the consumer. As an example, in the case of differentiated product design, its provision can best be seen in the window of a store or its presentation as an item on sale.

Based on these considerations lies the second theoretical approach that is discussed in this study, in which through a particular phenomenon later explained, consumer behavior will be studied by investigating the influence of purchase by reason and impulse.

The information is a decisive factor in the acquisition process of a product, as it is initially researched in the consumer's memory where it will seek prior recorded experiences. The other information source is the external environment through advertisements in flyers, newspapers, television, radio, billboards, bus exteriors, websites and social networks, among others.

In buying basic consumer goods such as food, cleaning and personal hygiene products, consumers generally search information at the point of sale itself usually represented by the supermarket. Consequently, the information in the store can exert a strong influence on consumer decision making (Engel; Miniard \& Blackwell, 2005). 
Currently, public information sources dominate much of the media, especially in the web platform, where magazines, newspapers, blogs and TV stations emit opinions about a particular product or service. However, spontaneous advertising space that represents the exposition obtained by a company in order to not pay the means of communication like the internet, which occurs quite significantly through social networks, is continuously increasing. Social networks are channels of digital relationships, where members connected through the Internet meet to discuss common issues (Mattos, 2011). In general, this interaction is made without interruption.

According to Bill Tancer, an expert on online behavior and CEO of Hitwise Serasa Experian (an agency that provides information about the interaction of people on websites) it is estimated that social networking sites are responsible for $62 \%$ of internet activity (Neto, 2009). In this sense, it is emblematic of recent research nominated Student's Online Usage: Global Market Trends Report, conducted based on testimonies of participants of QS World Grad School Tour between 2012 and 2013 (Vannozi \& Bridgestock, 2013), an event that takes place in different cities around the world, promoting the contact of university students and graduates from different countries. The report was based on the response of individuals to a questionnaire in 26 countries in Europe, Asia, Africa, Latin America and North America. Three key points were considered: time spent online, the device used to access the internet and preference for global social networks.

The study showed that Latin Americans behave in a similar form to students from other continents, with one exception: the frequency of the use of social networks. According to the survey, over $70 \%$ of Latinos said they use sites like Facebook, Twitter, LinkedIn, Pinterest and YouTube "all the time". Among the largest networks in Latin America being used are Facebook and YouTube, together making up 96\% of the responses to the question "Which social network do you use all the time?". In Europe, these sites were preferred by $81 \%$ and $84 \%$, respectively, and in North America, the choice of these occurred in $78 \%$ and $85 \%$. Still according to $Q S$, the use of Facebook in Brazil has increased more than 173\% per year (Cartola, 2013). Facebook is the most used social network in Brazil, with $71.1 \%$ of users, followed by YouTube and Twitter, the latter two with $10.5 \%$ and $1.5 \%$ preferred respectively (Cnt/mda, 2013).

These figures clearly show that there is a change in the habits of people who are increasingly interacting with each other and no longer appreciate receiving "ready" information, statically as that transmitted by the television or radio.

This study shares the understanding of Ardnt (1967, p. 293) who conceptualizes a specific form of product disclosure considered spontaneous, "the word of mouth marketing is a communication from person to person orally between a receiver and a communicator to which the receiver perceives as non-commercial information about a brand, product or service." In the context of new media, this form of communication, absent from a "business relationship", has been very effective with respect to the impact between the receptors, mainly to provide a greater burden of reliability among users who exchange such information. The bibliography on the subject is already supported by authors like Rosen (2001), who classifies this phenomenon as buzz marketing, by using stimuli to create a "buzz" about a particular product, reminding one of bees flying from flower to flower. In parallel with this image, humans are naturally talkative and thus seek to spread their enthusiasm, their experiences, commenting with each other about the qualities or advantages of a particular brand or service. For Chetochine (2006), buzz marketing is the very science of word of mouth.

Other researchers describe the importance of word of mouth marketing, noting that consumers often look for friends and family members for opinions on products and services (Engel, Miniard \& Blackwell, 2005). The credibility of word of mouth seems in principle to be larger than the other sources of information (Belch \& Belch, 2008), as there is a communicator exposure in an unremunerated way, that ends up putting their reputation at risk by recommending a product. This way of promoting products and services is usually practiced by the consumers who report their experiences, whether positive or negative.

One can no longer say that the word of mouth communication in a web environment is recent. Still, in 1995, the Amazon (Note 1) introduced customer ratings on its website in the second half of that year. Following the lead, a multitude of other retailers did the same (Sernovitz, 2012).

There was also the development of websites specializing in product evaluations, dedicated to sharing consumer opinion. They provide a huge and permanent record of word of mouth regarding almost every product and service imaginable (Sernovitz, 2012).

The advantages of the virtual word of mouth communication are numerous, such as the ease and speed in the collection and dissemination of information, discussions regarding products and services, the exchange of instant feedback and its permanent record. In summary, all information previously inaccessible to the ordinary person 
can now be found easily by the consumer, converted to user. Another multiplying factor action on the Internet is the increasing use of smartphones and tablets, but, more accessible to the population.

The word of mouth communication in the virtual environment occurs in online communities, forums and social networks that operate at different levels and platforms. These social networks should be understood broadly as social interactions that have been present since the dawn of civilization, when people get together to share common interests, deepening the ties of affection. When these social interactions take place in the online environment they are known as digital social networks that are shown as a differential interaction of individuals regardless of geographical boundaries, connected by political, cultural and ideological affinities. For a better understanding, these virtual networks are composed by people or organizations who share information, knowledge, interests and efforts towards common goals (Oliveira, 2011; Marchiori \& Oliveira, 2012).

After the introduction of e-mail, considered the first model of communication and file exchange between Internet users, significant developments have occurred in the interaction system between individuals, with greater coverage on the networks of contacts. In 1995 from the U.S. came Classmates, considered the first online social network, with the initial purpose of researching and enable the gathering of former classmates from school or college. Since then several models have been developed, notably in 2002 Friendster, well known at the time, allowing for closer relations of friendship of users with common interests; This network enabled the creation and dissemination of profiles as well as contact lists (Alexandre, 2012; Jesus, 2012).

In 2003 MySpace was launched with areas for archiving music, photos and a blog that could be customized by each user. MySpace, to be fully interactive, became one of the most popular social networks in the world, especially the United States. Linkedin appeared in 2003 with one new social networking proposal, focusing on the connection between professionals or entrepreneurs. In 2004 Orkut and Facebook were created, synonymous of worldwide success. Later in 2006 came Twitter, also representing one of the most accessed networks (Alexandre, 2012; Jesus, 2012).

Instagram was officially launched in 2010 and has the distinction of ability for the user to capture images, apply filters and publish them for free. The latest social network to enter the fray is Google+, officially launched in 2011, with 400 million subscribers, but with only $25 \%$ of active accounts. Despite the still small amount of information shared on Google+, the company invests in this service and has spared no investments in the sector. In addition to social networks, other digital marketing tools are standalone blogs and specific applications to exchange information between consumers such as Tripadvisor, Kekanto, foursquare, Foodspotting, among others (Oliveira, 2011; Daquino, 2012; Marchiori \& Oliveira, 2012).

Data from the 2012 Social Bakers consultancy show that Brazil was the country where the number of Facebook users grew with 29,723,760 new users in that year (Brasil, 2013). According to Facebook's own statistics released by Reuters in 2013, Brazil is the largest Latin American market in this segment, with 76 million monthly active users as of June 30 (Brasil, 2013).

These figures demonstrate the importance of social networking as a marketing platform, providing greater visibility of the product or brand targets of disclosure. Another factor linked to the social networking phenomenon contributing to its expansion is increasing the upward sales of smartphones in which Facebook bases its business strategy.

Due to its complexity, the interactions in digital social networks and their impact on the marketing environment is still configured as a relatively new territory for academia, which is why this research was designed. In this research, the social network Facebook was the observation platform of the type of communication known as word of mouth. To perform this study, we took as the object the fanpage of Dalí Cocina restaurant, situated in the neighborhood of Derby, in the central area of Recife. Through a literature review on the subject associated with the data analysis, the research tried to approach concepts around the real impact of virtual word of mouth, through empirical research and application of interviews.

Opened in 2009, the restaurant specializes in Mediterranean cuisine, especially the Spanish influence among the choices of starters, main dishes, snacks, cocktails, desserts and coffees, with the artist of that country, the greatest inspiration that conceptualizes the establishment categorized as a bistro, for the maximum number of 55 people. It works with À La Carte service and also delivery. The establishment is also one of the pioneers in the state capital to introduce and encourage communication with customers through social networks, which is why it was selected for this research.

It is worth mentioning that in the gastronomy scenario there are peculiarities with respect to the functionality of word of mouth that must be observed. In this sense, it is noted that "when it comes to asking for 
recommendations on places to eat and drink, we turn to people whose habits and tastes mirror ours. If our friends enjoy the food from Peter's, it is also likely we will appreciate it," (Salzman, Matathia \& O'reilly, 2003). Such affirmation leads one to understand the impact of word of mouth communication in the final choice of receivers (understood in this context as potential customers) which tends to influence as much or even more on consumer attitude than an action of traditional marketing, as this format adds subjective values such as familiarity of the information and references that are supposed sincere, by proximity.

Given these considerations, the main question worked in this research was: What is the influence of word of mouth communication in the Facebook audience of Dalí Cocina in Recife, PE?

\section{Digital Marketing}

In general, marketing can be conceptualized as efforts by companies to inform and communicate. According to Kotler and Keller (2006), marketing can be seen as the identification, creation, communication, delivery and monitoring of customer value. Another more detailed and updated definition is that of AMA (2004, p. 73) saying that marketing is an organizational function and a set of processes for creating, communicating and delivering value to customers, and the management of relationships with them in a way that benefits the organization and its stakeholders.

The focus of marketing is now on customers, those who buy the products and not who sell.

Considering specifically virtual or digital marketing, this can be defined as a set of strategies and actions through technology, or rather actions, computing and especially the internet, aiming for greater effectiveness in communicating with the public (Kotler, Kartajaya \& Setiawan, 2010). In virtual marketing, Internet connected devices are used in carrying out promotional activities which aim to promote products, businesses, services or brand attributes.

The Internet, the largest source of information on a global level, has additional and different characteristics from traditional media, free access to information, speed in the dissemination of information and the possibility of interaction between users through various tools like email and relationship networks among others. With the availability of such resources, there is a shift in consumer behavior, going from passive element to actively participating in generating useful information to companies that provide products and services (Kotler, Kartajaya \& Setiawan, 2010).

Companies, advertising agencies and liberal professionals represent some of the industries that have realized the potential of the internet in disseminating their products and ideas, using it in mass. This expansion has no limits as advertising and marketing agencies continually explore and develop new strategies to attract the audience. Virtual marketing, in turn, has the following properties: interaction, relationships, mobility, agility and technology. With technological development, an element was added to this virtual marketing, the mobile phone. This device, which has mobility as its most attractive feature, provides greater visibility to virtual marketing, using features like SMS and MMS, among others. (Bentivegna, 2002).

With the internet, buying behavior has changed dramatically: Customers can now search online all they want and can even complete the purchase at the same site. The interactive electronic media allows literally, anyone, to scour the world and make orders according to his or her comfort and convenience. Never before in human history have so many people been able to find so much information about so many things in one place. On the other hand, the use of the internet as an important tool in the search for any kind of information is no longer a novelty and has become a habit for people anywhere on the globe. Marketing was able to identify that the worldwide web is a potential channel for the promotion and distribution of products and services.

Virtual marketing is based on the same concepts of traditional marketing where individuals have their needs identified and met through the creation, dissemination, offering and exchanging products. E-marketing, however, has advantages such as its low cost with the possibility of participation of small businesses, providing a virtually unlimited space for advertisement, quick access and its range regardless of the geographic area.

With respect to social networking in the digital context, Kozinetz (1998) considers that a community is a group of people who share social interactions, social ties and a common "space", although mediated by a computer. The online interactions increasingly affect the behavior of people such as citizens, community members and consumers. According Kozinetz (1998), virtual communities of consumption are a particular subset of virtual communities whose interests are explicitly focused on consumption; in this type of community, the more informal discussion among the participants widen brand exposure and customer relationship. The premise is that the satisfied customer shares with his friends the satisfaction gained with a particular company and that creates visibility and a direct economical and effective benefit. Virtual communities such as Facebook and Twitter, in 
addition to allowing the meeting of strangers, have an edge over other media as they place emphasis on articulation and visibility of pre-existing social networks.

E-mail marketing is another powerful tool when directed at specific campaigns. Viral marketing also aims to promote the brand and is accomplished through creative actions that arouse emotion in the audience. The word 'viral' refers, according to Godin (2000), an idea-virus, in other words an intriguing and compelling idea, which draws the attention of individual and that even arouses in him the desire to share it. It is what happens when you send a video clip or a message over the Internet to a particular target. The message should be curious, funny, with the purpose to awaken some kind of emotion in the individual encouraging them to share it, which occurs through referral to other individuals, and so forth.

Traditional online advertising is more similar to the old conventional advertising with banners usually being used on important sites to increase brand visibility. Regarding the online search tool, it is another strategy that aims to better understand the profile of consumers and understand their needs and motivations of purchase.

The success of virtual marketing is measured by monitoring the results of all the different strategies used, being an essential subsidy for possible readjustments of the same strategies making them more efficient.

In this study the focus will be aimed at social media, specifically Facebook, since it exerts a strong influence on the spread of word of mouth communication, the theme of this research. On Facebook (Facebook, 2013) interactions occur between the participants in the form of profile or timeline, fan pages and groups. The fan pages (fanpages) are used by an organization or company to have a presence on Facebook. Regarding the different tools used by Facebook and of particular importance on fanpage, are noteworthy news feeds and the "like" button.

The news feed evaluates the following parameters: Affinity, namely the level of user interaction with the person or organization that created the content, obtained by analyzing the number of interactions of people visiting the fanpage, leaving messages on the wall, viewing photos, "liking", commenting or sharing content; Relevance, how many interactions (comments, "liked", shares) generated content; Time, how long the content has been posted. New messages have priority and are displayed ahead of older messages.

The "like" button is a feature that allows users to demonstrate that they appreciated certain information contained such as comments, photos and advertisements, among others. It is a simplified way that a user can say he liked it without leaving comments. By "liking" a brand the user displays publicly for his network of friends his interest in the brand.

\section{Word of Mouth Communication}

The concept of traditional word of mouth communication is discussed by different authors. In one of the first relevant works on the subject, Arndt (1967, p. 190) defined word of mouth as "an oral and personal communication between a sender perceived as non-commercial and a receiver, dealing with a brand, a product or service offered for sale." According to Engel, Miniard and Blackwell (2005) in word of mouth communication the informal transmission of ideas, comments, opinions and information occurs between two people, stressing that none of them is a marketing professional. For Sernovitz (2012, p. 29), word of mouth communication is "to give people a reason to talk about their products or services, and take measures to facilitate the occurrence of these conversations."

The word of mouth process is certainly the oldest form of marketing communication because it presupposes the exchange of positive or negative information directly between individuals without the need of means of support. (Kotler \& Keller, 2006). Marketing research on word of mouth communication began in the 1940s, after the Second World War (Butle, 1998) and in recent years the topic has been the subject of several studies in the field of marketing. Generally scholars define the phenomenon as an exchange, a flux of information, communication or conversation between at least two individuals.

Word of mouth communication is based on the theories of the flux of information that can be of two types: first, the information goes in two steps (Two-Step Flow Theory) migrating in a unique direction, in the sense of communication vehicles to opinion leaders and then to the mass of consumers (Schiffman \& Kanuk, 2000). Yet the theory of the multichannel flow of information considers that the media reaches both opinion leaders as well as the masses, arousing the people's attention about the existence of a product. This pursuit, according to Arndt (1967), consulting the opinion of people to confirm opinions of impersonal sources such as the media and the transmission of this recommendation from one person to another is called word of mouth.

Other authors consider that the phenomenon of word of mouth communication is explained by the strength of ties and social relations, the interrelationship between them and the flow of information (Brown \& Reigen, 1987). 
In this theory, individuals with similar attributes such as age, sex, education, social status and other traits usually attract and exchange more information with each other than people who do not have much in common.

These ties or relations can be of two types: form and content. The form indicates the strength of connection between the links and the content represents information or messages transmitted from one person to another. The ties can also be divided into primary and secondary. Primary or strong ties are characterized by frequent interactions that generally occur between family and close friends. The secondary or weak ties, on the other hand, represent the contacts established between acquaintances, such as participants in a church or association.

These ties interact. Strong ties create small networks where they circulate information, which are magnified by the weak ties that create bridges between these networks greatly expanding its scope. Weak ties are responsible for disseminating information, making it possible to expand their reach. The strong ties have greater power to influence the consumer decision process, due to its more affordable and reliable character.

Word of mouth is one of the most reliable forms of promotion, because people who have nothing to gain personally promote something, often putting their reputation at risk every time they make a recommendation. The sources of information considered most reliable by the consumer are represented by family and friends, and are more influential in the choice of services such as health care, schools and restaurants (Ikeda, 1997).

For the consumer to be considered a participant in a word of mouth conversation, the message being conveyed and the means of transmission of the message should be unlinked or independent of the influence of the company that launched the market (Silverman, 2001).

For Godin (2000), the consumer is saturated from the classic forms of interruption marketing, a practice that aims to bombard the client, the target, with advertising, promotions and incentives of all kinds to interrupt the flow of one's thinking and habits and make him succumb to the offer imposed. This author proposes a change in thinking by introducing the so-called permission marketing, which is the customer that searches and solicits the information about the product he wants from the company, in order to be convinced to buy the product or brand.

Among the forms of permission marketing, Rosen (2001) believes that the best way to advertise or sell products and services is the one where consumers commented among themselves (word of mouth communication) about the qualities and advantages of those items. In his reference book, Rosen (2001) describes buzz marketing as the industrial organization of rumor, of word of mouth, in favor of a brand or a product. This marketing model assumes that all people communicate constantly, "weaving" comments about the most different themes, giving opinions, agreeing, disagreeing, finally diffusing ideas.

At this point it is important to differentiate between the so-called organic word of mouth and amplified word of mouth or linear influence (Kozinetz, 1998). The first is that which occurs when people talk about a product only because they are satisfied with it, without the direct influence or monitoring of professional marketing. Amplified word of mouth communication already develops when there is an attempt by professionals to encourage and accelerate the marketing phenomenon. In this model, some consumers are seen as potential "opinion leaders" who can spread and affect the initial message more rapidly.

This type of marketing relates to the use of techniques geared to encourage and help people talk to each other about products and services, but without ever manipulating or falsifying information. Initially there is a stimulus to capture the attention of consumers who become a selling agent, transforming him from a passive recipient to an active issuer which will influence their social network.

Put simply, it can be said that word of mouth marketing is to act in the conversation in a way that makes people talk about you. One example is when a product or service is presented to influential people, opinion makers, expecting them to appreciate the product, publicize your opinion in your circle of influence and thus stimulating word of mouth. Through respect and approval of customers, they will do word of mouth without requiring any compensation.

Word of mouth communications can occur in person or through other means of communication such as telephone and internet. There are personal and impersonal sources of recommendations. The first group includes friends and family (Brown \& Reingen, 1987; Duhan et al., 1997). Vehicles of impersonal word of mouth marketing understand articles and commentaries from journalists, consumers and experts found in newspapers, magazines, trade publications and online discussion forums (Senecal, Kaliczynski \& Nantel, 2005).

Here again, it is emphasized that consumers should not notice any commercial or advertising purpose behind the recommendations; if this occurs then these communications do not represent word of mouth. This is the informal and independent side of word of mouth that makes it unique. 
With the advent of the internet, word of mouth has received new terminologies. Thus, it has been employed by some authors as synonymous with viral marketing, e-mail marketing, internet word of mouth, electronic word of mouth and digital word of mouth. The internet is the central component of this type of marketing being the element that distinguishes conventional word of mouth.

The internet allows for a more intense and faster communication by reason of the easiness of interconnection between people. In electronic word of mouth consumers do business with companies only after comparing official information from those companies, with those not official derived from other consumers, transmitted in virtual consumer channels (Kozinetz, 1998). Each consumer acts as part of the marketing communication, with the action potentiated by the multiplier effect of the internet (Phelps et al., 2004).

In viral marketing there is an initial stimulus-induced practitioner of marketing that captures the consumer's attention making it an agent of sale which in turn will influence other consumers and so on. The Internet extends the reach of the message through numerous tools previously registered, including social networks. An important aspect of digital word of mouth communication is that the message and the comments of the participants to be written, remain over time, being archived and may be accessed by other users.

In electronic word of mouth the participants may not have previous ties or relations between them representing weak ties, thus giving less credibility to the message disseminated. This aspect differentiates it from traditional word of mouth communication that is more reliable.

There are conceptual differences with respect to buzz marketing. While Rosen (2000) considers it as any word of mouth concerning a brand, other authors define it as an initiative produced by marketing with the intention of capturing people's attention and creating word of mouth.

It is not easy to theoretically define viral marketing from buzz marketing, often being applied interchangeably. However, some authors point to buzz marketing as the effect achieved by the actions of viral marketing, which can be complemented by other strategies including those involving traditional marketing. The internet and the development of numerous tools have arguably contributed to the spread of the practice of word of mouth, or buzz. This vehicle allows a wider communication, even among people who do not know each other personally.

Another important aspect of word of mouth is its virtual speed, disseminating information almost instantaneously. Through the Internet, a platform for aggregating people who speak of the products or services offered by a particular company, giving greater visibility to a conversation that has always existed, can be offered. Online social networks like blogs are examples of this new trend of word of mouth in the virtual world, representing a space for people to share their ideas. The virtual word of mouth also has a relevant feature as the ability to track and evaluate the opinions issued online.

The publishers are the clients and friends who spread the message of its brand through the usual word of mouth or through the Internet. The message in question, or the theme, need not be sophisticated, as it can be a service out of the ordinary, a unique taste, a pretty package and a funny name, among others.

Critical to the dissemination of the proceedings are the tools used in the word of mouth communication. Types of strategies include the distribution of cards or menus to patrons of a restaurant, the creation of blogs or the implantation of online communities.

The participation responsible for the brand or its legal representative in the conversations should be ongoing, not leaving people without answers. This participation can be made via e-mail and discussion forums. It needs to be emphasized that, especially, a complaint about a particular product should not be in relief, on the contrary, greater customer service in an attempt to minimize their dissatisfaction should be given.

Finally, the tracking of word of mouth in order to assess and understand what people are saying about you or the product you represent, can be gauged in blogs and other online communities, where participants publish their opinions. To monitor this communication allows one to understand what consumers really think about a product or service and provides a genuine level of understanding much more immediate and authentic than the technical information from traditional research.

Social media is a fertile field for the wide dissemination of the message and not one tool has the potential for expansion. Much of the everyday talk about goods and services has moved to this area. One can create a community or forum for customers of a particular product in just a few minutes on a popular social networking site like Facebook or MySpace.

This space represents an instant home for publishers who want to participate. From there the community establishes a public file that has the power to attract new individuals for future discussions. In this model, some 
points should be respected in relation to the consumer: their views should not be filtered, their questions and their doubts should be answered and resolved promptly and truthfully, and their opinion should be valued whether positive, neutral or negative.

\section{Research Methods}

In this section, the research methodology, which describes the principles and procedures through which the research problem was approached, will be presented (Taylor \& Bogdan, 2000).

The nature of this study is to cachet logical positivism since the verification of object propositions of research criteria will be based on observation and experience, which ultimately are consistent with the philosophical thought of logical positivism. In this philosophy, the aim of science consists of empirical evidence, catchable in sensible experience and treated as resources to logical analysis method.

The conception that the method of science is objective and that it always takes into account that the observer and his actions are in line with this study, which will be guided through the investigation of quantitative analysis of which relies on the positive frequency of repetition of observed events in the sample that in this case is the audience's Facebook of Dalí Cocina. Based on the objectives, this research can be classified as descriptive-explanatory (Malhotra, 2011). The descriptive point of view is in accord with the concept of Triviños (1987) in which the study aims to describe the facts and phenomena of a certain reality.

For better understanding, it should be identified which variables stand out in the phenomenon studied in relation to the object of research. The following research will be complemented by explanatory phase that is concerned with identifying the factors that determine or contribute to the occurrence of phenomena, aimed at the reason for things offered through the results. At this stage the verification tests, which are designed to reveal the causal relationships between variables raised, will be applied a priori.

The following operational diagram schematically represents the steps which have been developed in the study (Figure 1).

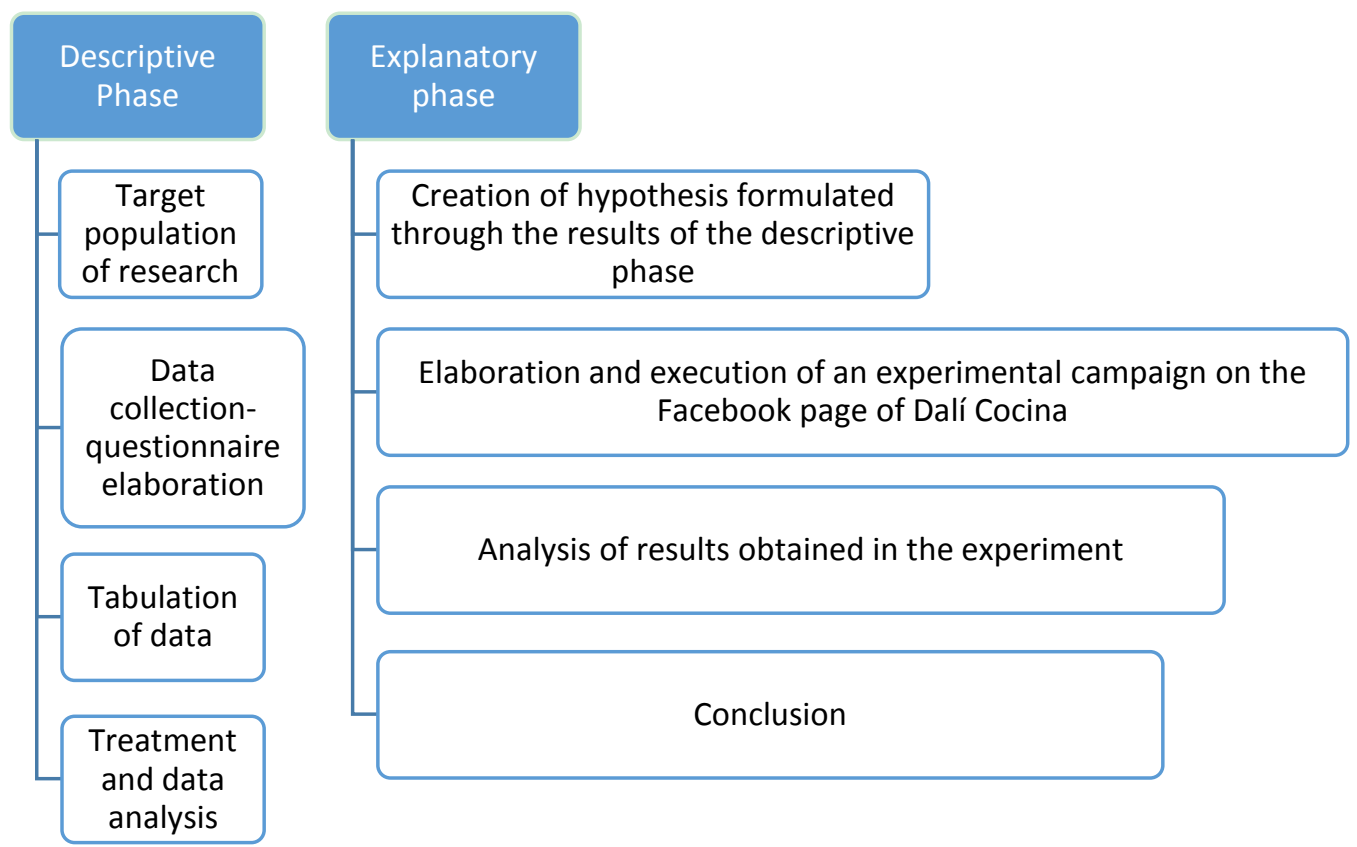

Figure 1. The research steps

The figure above shows that the method is divided into two parts. In the first phase, known as descriptive, a questionnaire was conducted to collect information required to be introduced in the second phase (explanatory) assisting in the creation of proposals that will be the future focus of the artificial marketing.

\subsection{Descriptive Phase}

As previously mentioned, this phase is descriptive in character, whose target is to know and interpret reality, 
seeking to interfere as little as possible at the same time (Churchill, 1999). This stage of the research the most relevant feature in restaurants that influences their dissemination will be initially investigated. Another aspect that will be researched corresponds to the type of the most reliable information source when choosing a particular restaurant. This research took place in form of a questionnaire, which was applied to the target population similar to the profile of the users of fanpage of the Dali Cocina restaurant.

The research method chosen was a survey, more appropriate to the object of the study in question, since it aims at seeking "what's happening" and "why the phenomenon is happening" (Freitas et al., 2000). Furthermore, this research presents the characteristics of the survey, since it is applied when it is not possible to control the dependent and independent variables, the natural environment is the best situation for studying the phenomenon of interest and the subject of interest occurs in the present or recent past (Freitas et al., 2000).

Prior to the data collection in a survey, a basic question is to define the amount of individuals that will be evaluated. The solution to this impasse is based on the study of some concepts, more specifically what signifies census and sample.

Census is understood as the examination of all the elements of a population or universe. If a population is infinite, the census is impossible. On the other hand, the sample is considered as a part of the universe or selected to represent the entire population group. The purpose of sampling is to generalize about a universe or a large population without the need to examine all components of the group.

One of the advantages of the census is the greater precision of the results since all units are studied and consequently there is no sampling error. Besides this aspect, the statistical treatment of the results is simpler. With respect to the sample, it is considered as favorable to its applied attributes to the lower cost and is generally faster in its execution.

The population studied in this research is finite, so it can be delimited. It was represented by a contingent of individuals who frequent restaurants and are concurrent Facebook users, regardless of any other individual attribute or characteristic. The same individuals voluntarily responded to a standard semi-structured questionnaire.

It is emphasized that the group of respondents had a similar profile as the users of the Dalí Cocina restaurant fanpage, which will be analyzed in the explanatory phase of this research. Once the target of the study population was small (only respondents of the questionnaire used), time and cost used to collect information were of little significance.

For this survey, there was also the need to obtain accurate individual information. Given these parameters, the census represented the most appropriate formula for this investigation. It is worth noting that there was no interference of the researcher in the thinking and actions of the evaluated audience. The destined locations for the distribution and administration of the questionnaires were selected based on the concentrated function of a large number of people and being geographically convenient to the researcher.

In view of the goals of the present study, the questionnaire was deemed the most appropriate instrument for data collection, assessing opinions, attitudes, preferences and individual behavior. The aforementioned was presented in almost its entirety, objective questions and structured answers, prepared in accordance with the theoretical framework.

Initially questions were presented to establish initial contact with the participants and, in sequence, the applicator presented the topics related to the focus of the study. With respect to the scales for the measurement of the facts to be searched, the Likert scale (1932) used five points, with the scores being: (5) strongly agree, (4) agree, (3) neutral, (2) disagree and (1) strongly disagree about a certain statement.

A pre-test questionnaire to 22 respondents chosen for convenience, over 18 years of age, attending restaurants and participating in social networks, was applied. This pre-test had the purpose to verify the level of acceptance and understanding of the issues addressed. Later there was an informal discussion with respondents on the areas of potential confusion (questions subject to misinterpretation), having been rephrased when applying the actual collection of research data.

\subsection{Explanatory Phase}

At this stage of the research the recorded data were worked, in order to analyze and interpret them, and identify their causes. In summary, the factors that contributed to the occurrence of phenomena were identified, and, thereafter, ideas were developed under logical deduction. Every effort has been directed to investigate the causes of the phenomenon. 
The explanatory research is processed through experiment that comprises different steps to be built: observation of facts and formulating hypotheses, testing hypotheses and developing theories.

The design of the experiment consists of a planned conduction form of tests that investigate a problem from the data collection.

According to the data obtained through the data collection instrument (questionnaire) used in the descriptive phase, hypotheses will be developed. They will be properly tested through experiment.

When the distribution of subjects by treatment is not random and there are no control groups, the alternative to research is the so-called quasi-experimental designs. The comparison between the conditions of treatment and no treatment should always be made with non-equivalent groups or with the same subjects before treatment.

In accordance with the objectives of this work, quasi-experimental design of Campbell and Stanley (1979), with a single group of individuals, namely, users of the fanpage of Dalí Cocina, was applied. This group was observed in two distinct time periods: between the 10th and 17th of December in the years 2012 and 2013. In 2012 the behavior of individuals was not subject to any external variable. Already in 2013 an external element to the monitoring of their response was introduced. If necessary, the experience would be repeated in three separate stages.

\section{Data Analysis}

In this chapter the instrument of data collection as well as the results and analysis obtained through it is explained. Later, in continuity, the analysis of the experiment emphasizing the most relevant aspects of the research is conducted.

\subsection{Data Analysis: Descriptive Phase}

The data collection instrument prepared seven understood questions, six formulated objectively and a subjective alternative allowing the respondent to describe his or her ideas. It is worth noting that three of the questionnaire questions included data on the socio-economic-cultural profile of the participants (Appendix 1).

After the validation of the questionnaire on days 06, 07 and 08 of December 2013, the application of the instrument for data collection was performed. The sample consists of individuals over the age of 18 , frequenting restaurants that regularly use social networking platforms.

The questionnaire was distributed by the researcher in two distinct locations: 1. Faculdade Senac de Pernambuco, chosen for convenience of the researcher, since it is an employee of this institution of learning, where participants included teachers, students and staff of administrative and operational areas. 2. Praia de Boa Viagem, selected due to the large influx of a heterogeneous public. The voluntary participation of individuals was without any kind of incentive for their collaboration. After a brief explanation of the formatting of its content, the questionnaires were delivered individually to each participant who issued their answers, without the participation of the researcher in the process.

150 questionnaires were distributed to individuals who have shown no objection to their participation, thus not having any refusal. However, twenty one questionnaires were partially answered, probably due to lack of observation of respondents to additional questions on the back of the sheet of paper. Thus, they were eliminated from the study. All valid forms that corresponded to one hundred twenty-nine were the object of the analysis.

The questionnaire was developed in order to meet two goals. First, to test the premise of the research, it was believed to be the modality of the word of mouth communication as the most reliable source of information when choosing a specific restaurant. Next was to identify the main characteristics of a restaurant that stimulate word of mouth communication.

Regarding the profile of the respondents the following results were found. Regarding the age of the participants, it has been pointed out that it was grouped into classes, to avoid a large extension table which would make the reading and interpretation of results difficult. Furthermore, the distribution of age classes also helps to visualize the behavior of the phenomenon as a whole as well as its variation.

According to Table 1 there was a relatively uniform frequency between groups, except for those under the age of 20. It is emphasized that despite this observation, there was a larger number of individuals aged between 21 and 30 years. 
Table 1. Age range of respondents

\begin{tabular}{cccc}
\hline Age group (years) & Frequency & Relative Frequency & Cumulative Relative Frequency \\
\hline Up to 20 & 15 & $11.63 \%$ & $11.63 \%$ \\
$21-30$ & 47 & $36.43 \%$ & $48.06 \%$ \\
$31-40$ & 33 & $25.58 \%$ & $73.64 \%$ \\
Over 40 & 34 & $26.36 \%$ & $100 \%$ \\
\hline
\end{tabular}

In table 2, the distribution of family income for participants is registered, taking as an indicator the number of minimum wage in 2013 amounted to $\$ 678.00$ reais. Family income is achieved through tracks considering the number of minimum wages in order to reduce the magnitude of responses providing a panoramic view of the behavior of the variable. Besides this, it allows one to detect a possible trend of a series of focus around a central value.

Once again, one perceives a relatively homogeneous distribution of the number of individuals considering the different levels of family income, with a slight concentration in the range of 1-5 minimum wages. The exception comprises the lower income group (up to 1 minimum wage) with a small number of individuals.

Table 2. Family income of the respondents

\begin{tabular}{llll}
\hline Family Income & Frequency & Relative Frequency & Cumulative Relative Frequency \\
\hline Up to 1 salary & 9 & $6.98 \%$ & $6.98 \%$ \\
$1-5$ salaries & 46 & $35.66 \%$ & $42.63 \%$ \\
$6-10$ salaries & 34 & $26.36 \%$ & $68.99 \%$ \\
Over 10 salaries & 40 & $31 \%$ & $100 \%$ \\
\hline
\end{tabular}

Interestingly, the results apparently bear a resemblance with the data obtained in Table 1. The largest number of individuals aged between 21-30 years and the highest frequency of family income between 1-5 minimum wages (MW) suggests that it is the same number of individuals. To ensure this thought, a table that correlates the three different age groups with an income of 1-5 minimum wages was constructed.

Table 3. Distribution of family income between 1-5 minimum wages by age of respondents

\begin{tabular}{ccc}
\hline Age group (years) & Frequency & Relative Frequency \\
\hline Up to 20 & 6 & $13.04 \%$ \\
$21-30$ & 18 & $39.13 \%$ \\
$31-40$ & 11 & $23.91 \%$ \\
Over 40 & 11 & $23.91 \%$ \\
\hline
\end{tabular}

It was demonstrated (Table 3), according to the initial thought, that the age group between 21-30 is the one which most often has a family income between 1-5 minimum wages. Although it is a relatively low household income it must be emphasized that this aspect probably does not compromise them going to restaurants since they usually correspond to single, newly married or having children few children. Or better, there is usually an impairment of their monthly income with larger sized expenses for being a small family.

It was necessary to measure the educational level of the respondents to better contextualize the sample, even though there is no prior restraint between the schooling and the potential to be a restaurant consumer.

In Table 4, the education level of the participants is presented, identifying that a very significant proportion of those, comprising of 56.6\%, have a higher education level and are postgraduates. Computed also were individuals with incomplete higher education, obtaining a total of $93 \%$. Of the respondents, only $7 \%$ solely have a high school education. 
Table 4. Educational level of respondents

\begin{tabular}{lccc}
\hline Educational Level & Frequency & Relative Frequency & Cumulative Relative Frequency \\
\hline High school & 9 & $6.98 \%$ & $6.98 \%$ \\
Incomplete higher education & 47 & $36.43 \%$ & $43.41 \%$ \\
Higher education completed & 37 & $28.68 \%$ & $72.09 \%$ \\
Postgraduation & 36 & $27.91 \%$ & $100 \%$ \\
\hline
\end{tabular}

Starting from the idea that the level of education does not interfere with going to restaurants, we proceeded to a more detailed study of the group of participants who had completed up to the high school level. The table below (Table 5), contrary to what was expected, it is observed that there is a relationship between a low educational level and a lower frequency in frequenting restaurants, approximately once per month in about $56 \%$ of cases.

Table 5. Mid-level of education and the frequency of respondents in going to restaurants

\begin{tabular}{lcc}
\hline Frequency of going to restaurants of mid-level respondents & Frequency & Relative Frequency \\
\hline Once per month & 5 & $55.56 \%$ \\
Once every 15 days & 2 & $22.22 \%$ \\
Once per week & 2 & $22.22 \%$ \\
Twice per week & 0 & $0 \%$ \\
More than twice per week & 0 & $0 \%$ \\
\hline
\end{tabular}

From there it was questioned whether this association was real or fictitious, merely reflecting the economic status of this group, since it is well known that the level of education impacts the family income. For this purpose an additional table (Table 6) was built, which clearly shows that participants possessing a high school diploma have more than $55 \%$ of family income up to 1 minimum wage. These data indicate that the economic issue of individuals is more important than the education level of the same, in the frequency as to their dining at restaurants.

Table 6. Mid-level education and family income of the respondents

\begin{tabular}{lccc}
\hline Family Income of mid-level respondents & Frequency & Relative Frequency & Cumulative Relative Frequency \\
\hline Up to 1 salary & 5 & $55.56 \%$ & $55.56 \%$ \\
$1-5$ salaries & 2 & $22.22 \%$ & $77.77 \%$ \\
$6-10$ salaries & 1 & $11.11 \%$ & $88.88 \%$ \\
More than 10 salaries & 1 & $11.11 \%$ & $100 \%$ \\
\hline
\end{tabular}

As to the question formulated in order to prioritize trust in information sources, the alternatives presented were graded 1-5 by the participants according to the model of the Likert scale. On this scale, the number 1 represents the most reliable choice and the number 5 the less reliable, so the answer to the lowest level in its entirety represents the most reliable. The individual indices for each alternative were added to obtain its frequency relative the total number of responses.

Information sources included among the possible answers are justifiable because they cover almost all of the available sources beyond the vested interest of this research, that is to know the importance of the indication of friends (word of mouth). With that being said, the results of this analysis could serve as a basis for evaluating the importance of social media in word of mouth communication compared with other communication channels, a later stage of this current research. Below are the data collected. 
Table 7. Types of more reliable information when choosing a restaurant by respondents

\begin{tabular}{lcc}
\hline Information sources & Number & Ranking \\
\hline Indication of friends and relatives & 191 & 1 st \\
Guides such as Veja Recife and Quatro Rodas & 369 & 2nd \\
News Press & 380 & 3 rd \\
Advertisements on the Internet and social media & 404 & 4 th \\
Advertisements in magazines and newspapers & 418 & 5 th \\
\hline
\end{tabular}

As shown in Table 7, the alternative "indication of friends and relatives", in other words, word of mouth communication, represented the most reliable information source. On the other hand, ads in traditional media (magazines and newspapers) and electronic media (internet and social networks) are less reliable. It is emphasized that ads on the internet and in social networks represent paid advertising material usually made available on the online platform, often appearing in the form of banners or blog posts and therefore do not correspond to word of mouth communication.

For the purpose of making it more comprehensive and to reiterate the importance of the indication from friends and relatives as a source of information indication at a restaurant, a new table (Table 8) was created.

Table 8. Frequency of the types of information most trusted by respondents

\begin{tabular}{lcc}
\hline Information sources & Frequency & Ranking \\
\hline Indication of friends and relatives & 101 & 1 st \\
News Press & 15 & 2 nd \\
Guides such as Veja Recife and Quatro Rodas & 14 & 3 rd \\
Advertisements in magazines and newspapers & 12 & 4 th \\
Advertisements on the Internet and social media & 10 & 5 th \\
\hline
\end{tabular}

In table 8 , considering the item defined by participants as the most reliable, it is verified that the indication of friends and relatives got more than $66 \%$ of responses, in second place the press releases appear as the most reliable information vehicle. However, it is noted the expressive relative difference to the numbers obtained from the two alternatives individually.

Other relevant data is the demonstration in this table indicating that the friends and relatives reached a much higher figure than all the answers considering the sum obtained in other alternatives.

Considering the characteristics of a restaurant, defined as the most attractive to customers, resulting in a possible disclosure of the same to third parties, solicited a written position of respondents. A multiplicity of responses occurred, with those that were repeated more frequently, at least on six occasions, being selected.

In case the respondents indicated various aspects, these were also considered and quantified. In the table below are recorded the most relevant parameters in the opinion of the respondents.

Table 9. Characteristics that influence the referral from a restaurant by the respondents

\begin{tabular}{lcc}
\hline Characteristics of the Restaurant & Frequency & Relative Frequency \\
\hline Treatment & 114 & $25.39 \%$ \\
Quality of plates & 105 & $23.38 \%$ \\
Type of food & 69 & $15.37 \%$ \\
Ambience & 44 & $9.8 \%$ \\
Compatible price & 40 & $8.9 \%$ \\
Cleanliness & 32 & $7.13 \%$ \\
Location & 16 & $3.6 \%$ \\
Presentation of the plates & 9 & $2 \%$ \\
Parking & 8 & $1.78 \%$ \\
Menu variety & 6 & $1.34 \%$ \\
Good music & 6 & $1.34 \%$ \\
\hline
\end{tabular}


It is clear from table 9 that the most relevant disclosure in a restaurant, in the opinion of customers, is understanding the service and the quality of the dishes offered; the summation of both reaching the percentage of $48.77 \%$, namely, almost half of the other related items. It is evident the importance of the service at a restaurant is translated by the kindness, speed and personalization of attending to the clients, one aspect that has been pointed out in other studies.

It is interesting to observe that unexpectedly the price of the dishes offered occupied the fifth position as the influential factor in the dissemination of a restaurant. This data informs that the customer does not feel exploited when they paid a fair price for the dish and the service consumed.

The quality of the dishes is usually a point in common between the various restaurants, configuring itself practically as a mandatory item. Thus, it arises according to the expectations of the researcher, the service of the restaurant as the most prominent item by the respondents.

These data indicate the need to qualify the local workforce to operate in food establishments outside the home, an aspect which is often underestimated. In summary, the data reinforced by the choice of restaurant ambience in fourth place of importance by the respondents, indicate that it is of paramount importance within the lived experience of each restaurant. The measurement of these results provides the ability to prioritize some points for its application in restaurants, allowing a possible increase in the dissemination and growth of potential clientele.

The following table shows the assiduity of respondents regarding their turnout at restaurants, considering the maximum time interval of one month as a reference. It found an increased frequency of visits, almost $30 \%$ once a month. It is interesting to note that the figures relating to visits to the restaurant once a week and once every two weeks (every 15 days) represent the total of $48.06 \%$. These figures highlight that there is a regular public that frequents restaurants in our city, reflecting the data that shows Recife as the third national gastronomic hub. The lowest index recorded corresponded to the frequency of twice a week in going to restaurants.

Table 10. Frequency of visits to a restaurant by respondents

\begin{tabular}{lccc}
\hline Frequency of going to restaurants & Frequency & Relative Frequency & Cumulative Relative Frequency \\
\hline Once per month & 38 & $29.46 \%$ & $29.46 \%$ \\
Once every 15 days & 28 & $21.70 \%$ & $51.16 \%$ \\
Once a week & 34 & $26.36 \%$ & $77.52 \%$ \\
Twice a week & 13 & $10.08 \%$ & $87.60 \%$ \\
More than twice a week & 16 & $12.40 \%$ & $100 \%$ \\
\hline
\end{tabular}

Finally, considering the utilization of the digital social network Facebook by respondents, it is perceived according to table 11, their frequent use, with $86.8 \%$ of them registering their daily use. These results are consistent with research showing that, globally, Brazilians often occupy the leading position in the average hours connected to social networks. The data obtained keep parallel with regulars of the fanpage of Dali Cocina, which were targets of the experiment conducted later.

Table 11. Utilization of Facebook by the respondents

\begin{tabular}{lccc}
\hline Assiduity on Facebook & Frequency & Relative Frequency & Cumulative Relative Frequency \\
\hline Every day & 112 & $86.82 \%$ & $86.82 \%$ \\
Once a week & 13 & $10.07 \%$ & $96.90 \%$ \\
Once every 15 days & 2 & $1.55 \%$ & $98.45 \%$ \\
Once per month & 2 & $1.55 \%$ & $100 \%$ \\
\hline
\end{tabular}

Based on the results obtained through the interview itemized in detail in the lines above, The following propositions can be formulated: Proposition 1 - A positive customer experience such as the good service in a restaurant possibly results in the disclosure of the same, establishing word of mouth communication; Proposition 2 - Reflecting this positive communication of the customers of the restaurant, occurs an increase the audience of the 
same fanpage.

\subsection{Analysis of Experiment: Explanatory Phase}

In order to occur, the experiment traditionally must choose between the laboratory setting or field. The laboratory environment is the preferred choice of researchers due to the possibility of greater variable control. However, before the introduction of new technologies, real digital environments become possible places to conduct the experiment and, therefore, its original scope allows a necessary control of variables in addition to having the highest possible realism, which is the observation of the phenomenon in a natural environment.

In the case of this research, the experiment took place on the digital platform of Facebook, specifically the fanpage of Dali Cocina. Presented next is a brief history of the relationship of the restaurant with Facebook fo better contextualization of the theme.

Although Dali Cocina had started its activities in November 2009, it was only in September 2011 that its fanpage was created. The fanpage on Facebook was developed by the owner for the purpose of acting as means for promoting the restaurant and in response to the constant requests of customers who sought a source of information about the restaurant in addition to a channel that would allow feedback on the service provided.

At its inception, the fanpage adopted a contingencial strategy guided by the feeling of the owner of restaurant and in return observed the customers. The owner edited and monitored the page by creating random posts to advertise the services of the restaurant or introducing themes he believed to be of interest to followers on Facebook.

Although the owner noticed an increase in the frequenters of the fanpage of his restaurant since its inception, it was only in November 2011, after hiring a professional marketing team, that the page had an influx of participants in a faster and uniform way.

This period was when the first promotional campaign using fanpage, where a Samsung smartphone, the Galaxy S2 model, the object of desire at the time, was raffled. This promotion lured in a large number of people and generated tremendous interest and divulgation on the part of customers themselves. The action stimulated customers to visit the restaurant, where they were photographed with the dish they consumed and then posted it on their own Facebook. The customer whose photograph was most "liked" on the fanpage would win the smartphone.

This was first action developed at the restaurant with the intention of stimulating word of mouth communication and clearly revealed its importance in spreading the Dali Cocina brand in the market. It was clearly observed during hte promotion the convergence of new potential customers seeking the restaurant for both the promotion as well as to ascertain whether the information disseminated by word of mouth was, in fact, real.

There were other prompt actions that have provided greater visibility of the fanpage, stimulating its vertical growth. At the time this was written, it had a total of 7,224 likes. According to Figure 6, comparing the fanpage of Dali Cocina with that of other restaurants with similar offerings in the city of Recife, it confirms that the restaurant studied ranks second in number of participants. It is also evident that the difference between the top two places is insignificant.

Once the service in the restaurant was considered the main triggering factor for word of mouth communication, the strategy of the experiment consisted in the solicitation of some individuals to disclose a compliment on their timeline regarding the service of Dali Cocina in an attempt to boost word of mouth communication. Each guest created his or her interaction in a personal, non-standardized way. However, all participations were done on the same day: December 12, 2013.

The period of one week was set from December 10-17, 2013 for the accurate analysis of the results, since it would be necessary for comparative effect the evaluation of the data obtained before, during and after the experiment.

Of a total of 15 individuals initially invited, twelve effectively participated in the intervention as researchers-actors, who fulfilled tasks previously determined relative to the experiment. Their participation was requested randomly being known by the researcher and, consequently, easily accessible. Later it was discovered that some of these individuals were considered trendsetters or "evangelists" (those whose enthusiasm for the brand carries high power of persuasion among others) by the repercussion size that occurred in the experiment.

The "evangelists" can be connectors, mavens or persuaders. Connectors are individuals who have a wide range of acquaintances with whom they maintain contact; mavens are those considered experts on some subject and, finally, persuaders are people who have the gift of being able to convince and enthuse new individuals to 
participate in the "flow" (Chetochine, 2006).

It is now known that the impact of a message depends largely on the quality or even the credibility of the sender and not just the content. The "evangelist" is who provides credibility to the message. If the initial participation in spreading the cause was not held by influential people, probably the effect of word of mouth communication would happen, but more insidiously.

Based on the experiment, it was believed that there would be positive word of mouth communication about the service at Dali Cocina, which in turn would trigger an increase in of the fanpage audience demonstrated by the higher number of "likes". Finally the action culminated in possible increase in the number of restaurant patrons. It is emphasized that this latter aspect was not measured, by not being part of the proposed scope by this research; however data relating to this matter will probably be worked on in future investigations.

The comments made by the invited participants of the experiment were as diverse as possible, but always focusing on the service of Dali Cocina. Some comments caused a greater impact, with greater repercussions among internet users generating a greater amount of interactions.

In response to posts created by the guests we obtained a total of 235 "likes", 86 interactions and 2 "shares". On the fanpage of the restaurant after completion of the intervention, 323 "likes", 36 interactions and 9 "shares", concurrently. Also an addition of 25 new followers of the fanpage was observed.

For clarification, "likes" means that Internet users read the publication, or even better, that the publication has generated empathy in visitors. As for interactions, it is understood that the matter came to the attention of the visitor more intensely, to the point of even going to the trouble to write a comment. Finally, "sharing" in general means that the subject was so appealing to the internet surfer that it resulted in his sending it to other individuals associated with him. Therefore, all of these aforementioned actions become configured as word of mouth communication expected by the researcher, being the result of the stimulus provided by the researchers-actors of the experiment.

As previously mentioned, although the experiment was held on December 12, 2013, the resulting data were evaluated during the same period of one week from December 10-17, 2013. This time limit was taken as reference due to the knowledge of the seasonality of the restaurant as a business venture.

Control of the external variable (intervention of guests) was obtained through correlating data collected during the same time period the previous year (2012), relative to the audience and the interaction on Facebook associated with Dali Cocina. To reiterate this point, the comparative study aimed to identify the response and its rising intensity of stimulus applied in the experiment. Graph 1 below shows the number of individuals who commented about Dali Cocina in the period between December 10-17, 2013.

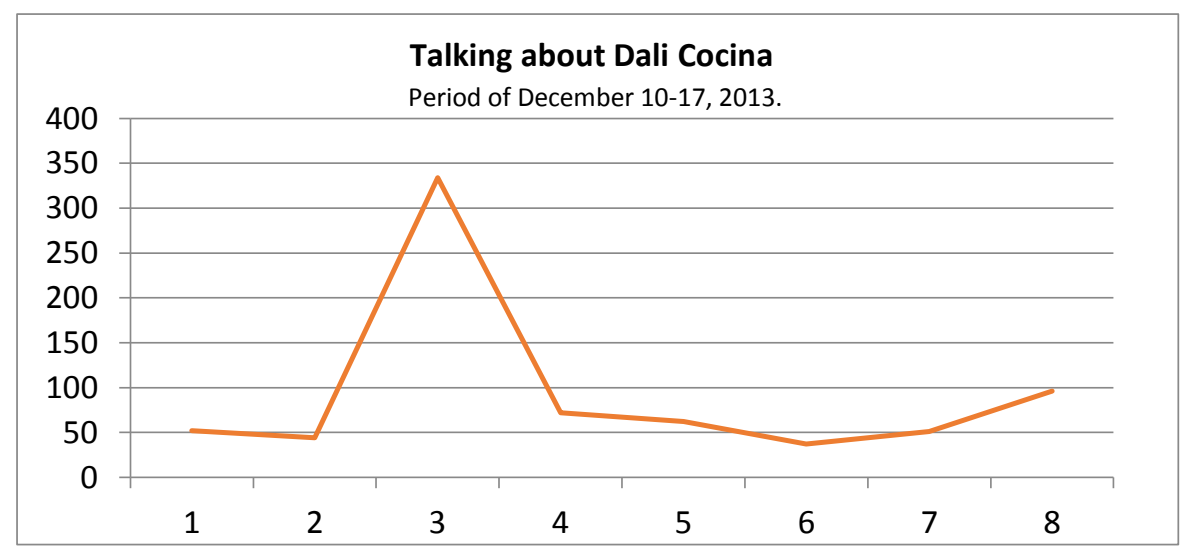

Figure 1. Number of individuals commenting about Dali Cocina (2013)

It is found as expected a sharp rise in the number of individuals who commented about Dali Cocina, an increase of over $300 \%$, shown by the peak at point 3 of the chart above, which exactly matches the date of the experiment, the twelfth day of December 2013. It is also perceivable the instant drop in the number of participants on Facebook, immediately in the subsequent days, approaching that seen prior to the experiment. These data undoubtedly demonstrate that the intervention held on December 12, 2013 was the triggering factor of the phenomenon. 
Figure 2 shows the overlap of the data obtained in the period of December10-17 of the years 2012 and 2013 , relativo to the number of individuals who commented about Dali Cocina. This graph confirms the results obtained in Figure 1.

There is a tendency of linearization of the numbers in the year 2012, unlike the peak evidenced in 2013 during the experiment. Except for the day of intervention, there is a similarity in the pattern of the graph in both periods. The only contrary event in the two years analyzed corresponded to the realization of the experiment, and therefore it is obvious that this procedure was responsible for changing the behavior of the frequenters of Facebook.

Noteworthy still is that after the completion of the experiment, the numbers declined to previous levels, thus demonstrating that if there is no continuity of word of mouth communication, a perpetuation of the phenomenon does not occur. It is identified that, at point 8 of the graph of the year 2013, there is an increase in the number of individuals who commented about the restaurant without known cause, but such movement is their own business and does not detract from the validity of the experiment.

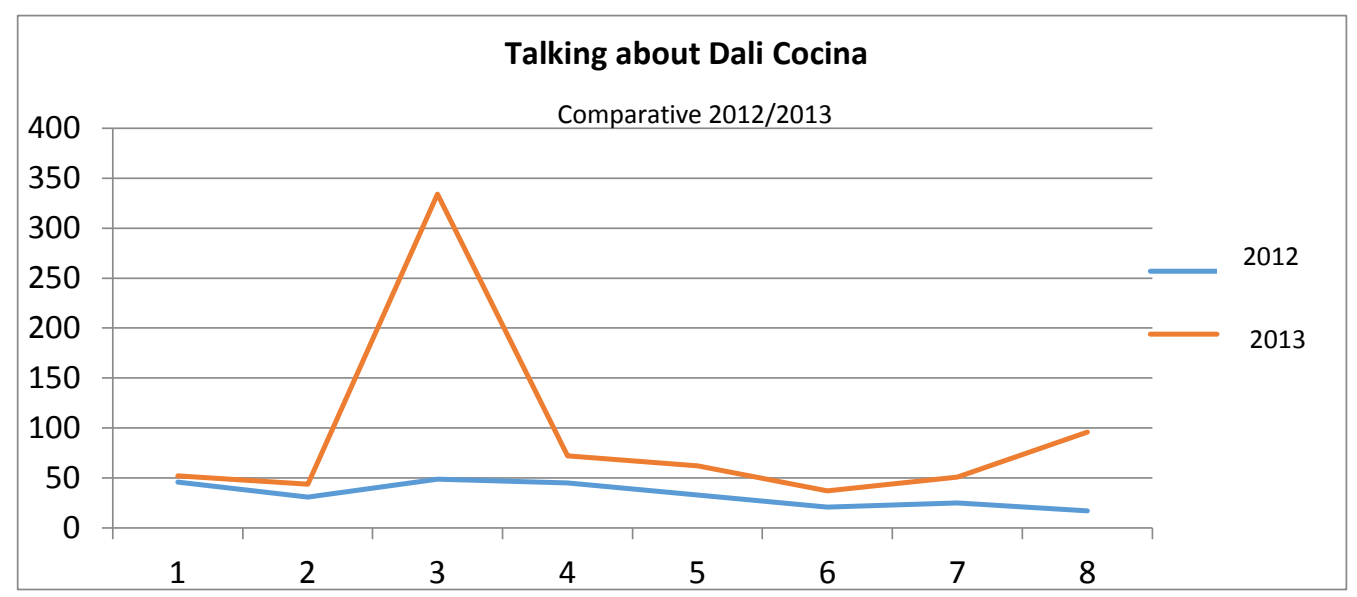

Figure 2. Number of individuals commenting about Dali Cocina (2012-2013)

Figure 3 shows the number of views on the Facebook page of Dali Cocina during the period of December 10-17, 2013. A similar pattern was evident to the previous graphs peaking during the experiment, but reaching a higher level. The number of views in the days preceding the intervention was less than 1,500; views on day of the experiment surpassed 36,000. In the two subsequent days there was a marked decline in numbers especially on the second day, returning to the original figures relative to the period before the intervention.

Views of posts are simpler and faster for Internet users than the exercise of interacting with comments, which probably justifies the sharpest peak in graph 3 with respect to the prior ones.

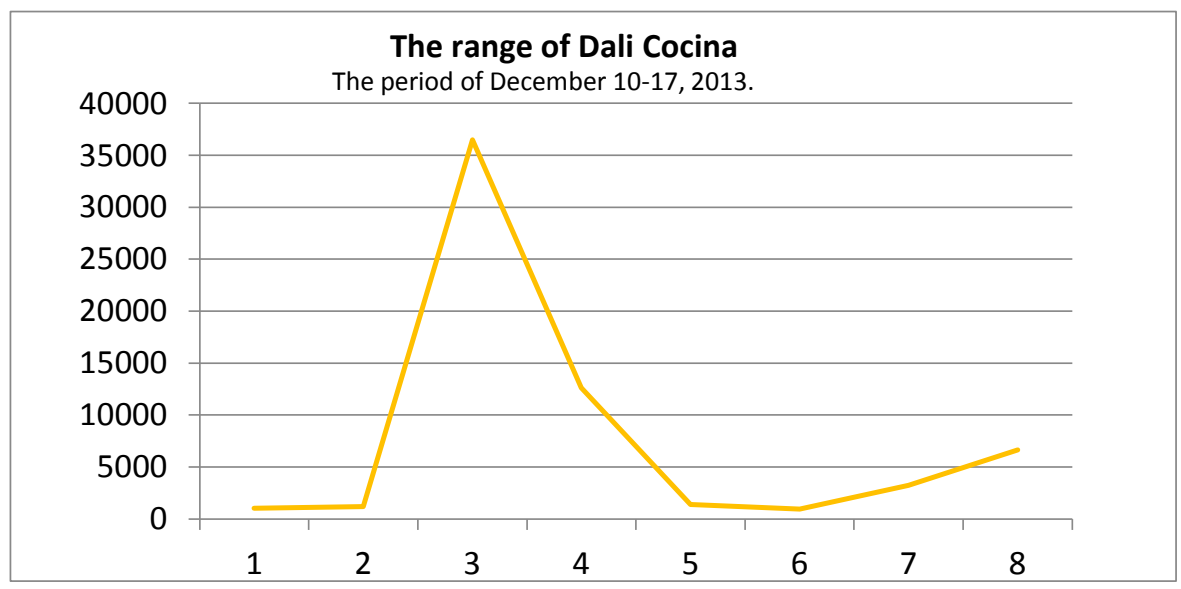

Figure 3. Number of views of Dali Cocina (2013) 
Figure 4 below outlines a comparison between the number of views of Dali Cocina on Facebook in the period of December 10-17, 2012 and 2013. The difference is clear between the number of views in the two periods evaluated. While in 2012 the numbers remained stable, on December 12, 2013 there was an abrupt increase in numbers corresponding to the date of intervention. On the following day of the experiment there was a significant drop in the number of views that became progressively larger over the course of days.

The speed in the change of the pattern of numeric views of Dali Cocina on Facebook at the time and immediately after the experiment undoubtedly demonstrates that word of mouth communication is the key element of the phenomenon.

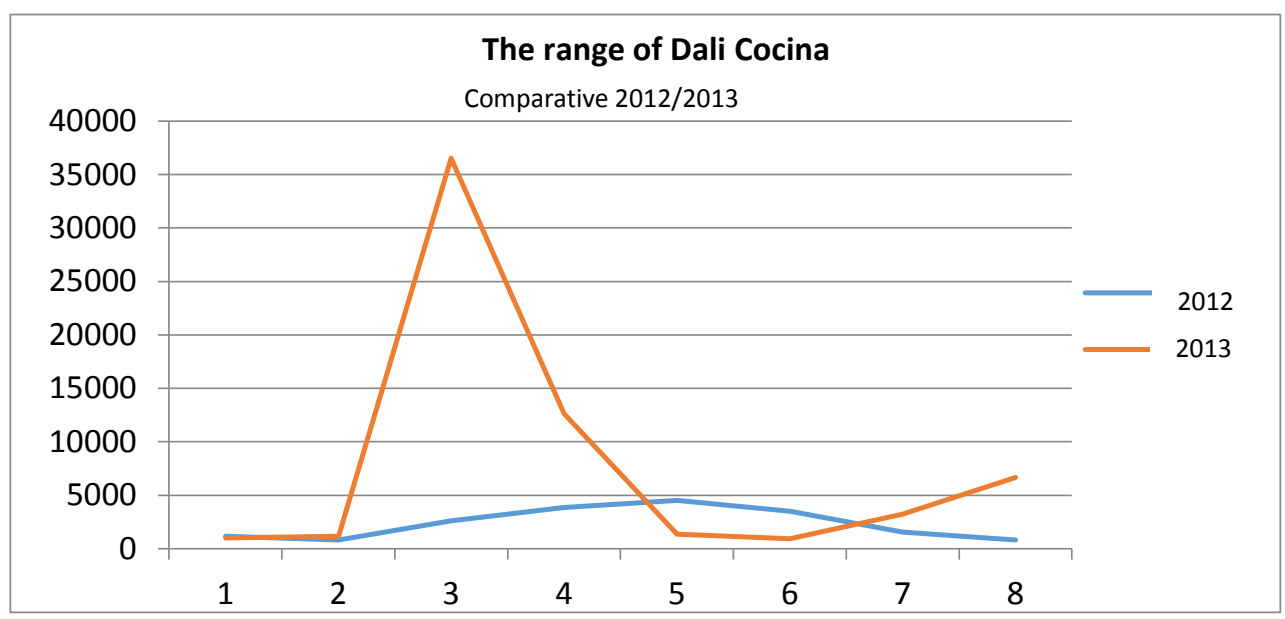

Figure 4. Number of views of Dali Cocina (2012-2013)

Figure 5 shows the number of people who joined the fanpage of Dali Cocina in the same period assessed during the experiment. The pattern was reproduced as seen in the previous graphs. On December 12, 2013, twenty five new individuals began to follow the fanpage of the restaurant.

There was, however, a significant increase in numbers when compared to those relating to previous dates, with the entry of up to 2 people per day. It is observed that in the two subsequent days, despite the decline in the number of new "likes", there was still a greater number than in the previous phase of the experiment. Since then the numbers have returned to the original pattern.

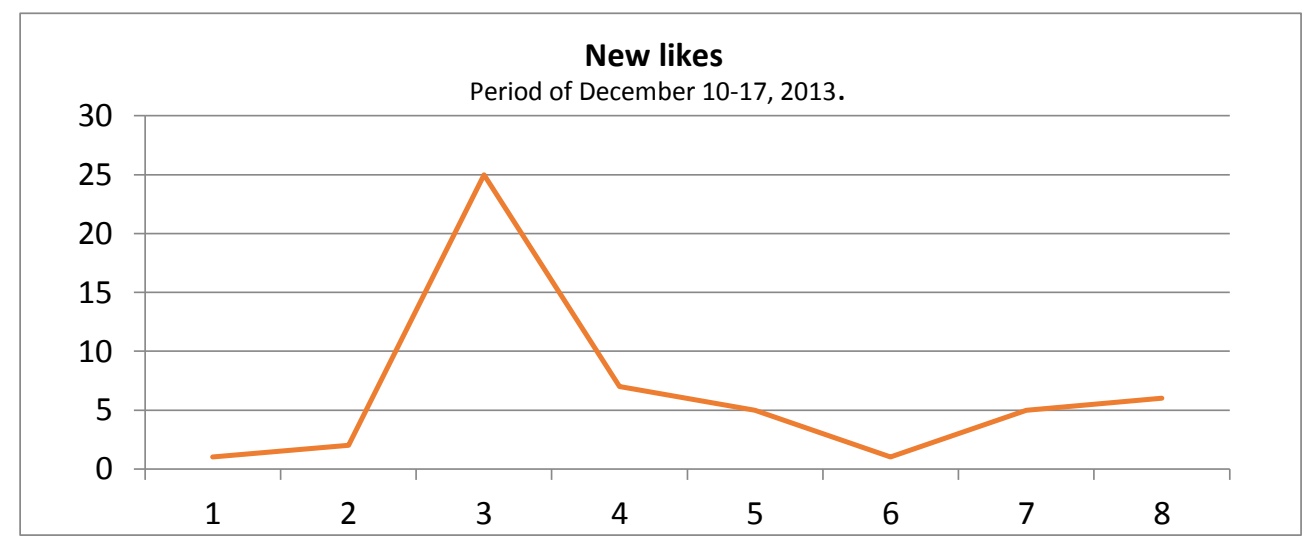

Figure 5. Number of new likes of Dali Cocina (2013)

Figure 6 correlated the number of entries of new participants on the fanpage of Dali Cocina in the subsequent two years (2012 and 2013) in the same period, between December 10 and 17. Although the line of graphics is not uniform, in 2013 there was a sharp rise to a marked level, keeping close relation with the date of the experiment. 
The instability of this variable demonstrated by the oscillation of the lines, especially in 2012, the subjectivity can be justified in the public interest to the themes disclosed on the fanpage.

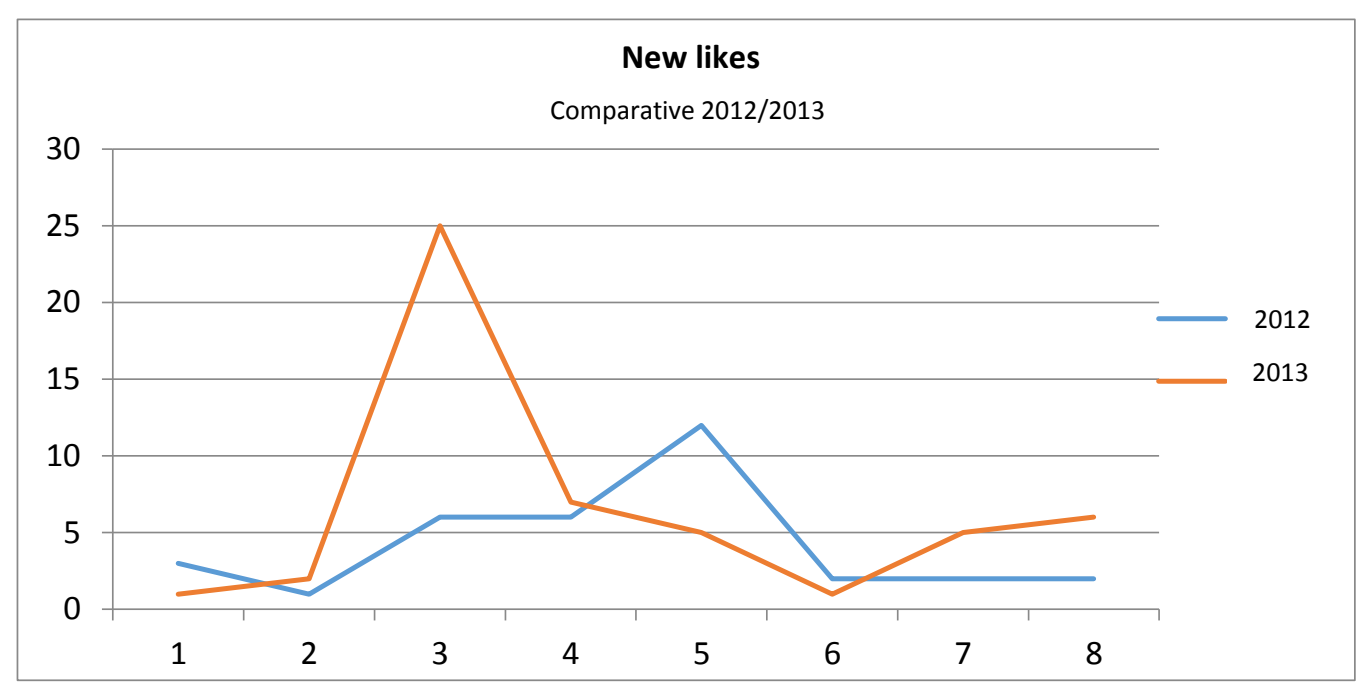

Figure 6. Number of new likes of Dali Cocina (2012-2013)

Through the analysis of data collected in the empirical stage of this work, innumerous aspects can be perceived regarding the research question initially proposed. One of the principal answers encountered is that virtual word of mouth communication tends to be a tool as efficient, or even more so, than traditional advertising, to draw the attention of the customers of Dali Cocina. This evidence is consistent with the assertions of Arndt (1967), highlighting the effectiveness of impersonal sources in influencing the consumer. The greater interaction between consumers in the fanpage environment of the restaurant makes the relationship between customer and company become a primary factor in the success of the actions.

\section{Conclusion}

This present chapter brings together the main discussions regarding the results obtained in the research, as well as their likely repercussions. The general objective of this work was to verify how word of mouth communication exerted by the frequenters od the fanpage of Dali Cocina could influence in attracting new propagators on Facebook. To this end an experiment was created, whose triggering factor was pre-selected through the instrument of data collection, more specifically a questionnaire, applied to individuals with profiles similar to the frequenters of the fanpage of the aforementioned restaurant.

The results of the experiment showed an amplification of word of mouth communication with the accession of new participants in a short period of time from an initial stimulus.

Word of mouth reached its climax on the day of the experiment with an abrupt fall in the following days, showing that the phenomenon is ephemeral, if there is not the creation of new stimuli. These data indicate the need to continue the process, making the audience anxious for new things. This is where a professional marketing team is needed, being specialized and engaged in this type of action.

It must be emphasized here that the reason for the experiment was not to determine the impact of word of mouth communication regarding the clientele of Dali Cocina, since the period of the action was too brief to promote any noticeable change in the behavior of patrons of the establishment.

Word of mouth communication is currently considered one of the most important marketing tools in promoting products and services (Sernovitz, 2012). With the expansion of digital social networks, this marketing technique is a favorable environment for its application. Within this context, the focus of this present research was centered on the practical applicability of word of mouth communication directed specifically to Dali Cocina on Facebook, considered as the social network with the largest number of users and the fastest growing in Brazil (Brasil, 2013).

During the development of this research, Facebook has demonstrated its functionality as a means in the development of work in marketing. The excellent performance of this social network is largely due to the 
possibility of benchmarking results for the users' profiles as well as their frequency of access and interaction, available in real time on fanpage of which is the target the determined investigation, as had occurred in particular with Dali Cocina.

The data obtained by the researcher on his own fanpage through WebAnalytics were analyzed to establish the results of the experiment. This innovative Facebook profile makes it an important and promising tool in academic research.

Another important aspect of this present study was to identify through the questionnaire administered to users of restaurants on the main elements that influence the divulgation and likely turnout to these establishments. An example is given by the response of those interviewed when considering that service is the priority among the various items offered by the restaurant. The research is relevant as well, because of the possibility of extrapolating these data to the practice of the restaurants in the city of Recife, making these employers more efficient in managing their businesses.

So that the message conveyed by the transmitters will be attractive and cause an impact, it is necessary that the topic is of interest to the community. Context is considered a support, an amplifier of cause (Chetochine, 2006). In this study, the triggering stimulus of word of mouth communication corresponded to the service at the restaurant, which was once the most prominent item considering the analysis of the questionnaire.

It was proven that it is the poor service at eating establishments outside the home, the context which magnifies the repercussions of the message. Therefore, a discussion on the topic initiated by those invited to participate as coadjuvants in the performance of the experiment seemed the most attractive way to capture the attention and accelerate word of mouth communication. The triggering stimulus of the word of mouth phenomenon was specific to this research, not being possible to ensure their applicability in future studies.

The significant increase in the number of individuals who joined the Dali Cocina fanpage on the day of experiment proves that the experience of digital word of mouth communication was the factor of attraction of these new elements. Again it is stressed that the strength of word of mouth communication is a change from usual patterns of behavior.

\section{References}

Alexandre, C. (2014). História das redes sociais. Retrieved from http://agencianoah.com.br/blog/2012/09/historia-das-redes-sociais/

Ama (American Marketing Association). (2014). Definition of marketing. Retrieved from http://www.marketingpower.com/AboutAMA/Pages/DefinitionofMarketing.aspx

Ama. (2014). Branding: defined. Retrieved from http://www.chicagoama.org/behind-branding-scenes

Amaral, J. C. (2014). O tamanho da internet no Brasil: somos hoje 105 milhões de internautas. Retrieved from http://www.joaocarlosamaral.com.br/index.php?id=14240

Ardnt, J. (1967). Role of product-related conversations in the diffusion of new products. J Mark Res, 4(1), 291-5.

Barbosa, R. R. (2002). Inteligência Empresarial: uma avaliação de fontes de informação sobre o ambiente organizacional externo. Revista de Ciência da Informação, 3(6), 1-15.

Belch, G. E., \& Belch, M. A. (2008). Propaganda e promoção: uma perspectiva de comunicação integrada de marketing (7th ed., p. 427). São Paulo: McGraw-Hill Interamericana do Brasil Ltda.

Bentivegna, F. J. (2002). Fatores de impacto no sucesso do marketing boca a boca online. Revista de Administração de Empresas FGV-EAESP, 42(1).

Bickart, B., \& Schindler, R. M. (2002). Expanding the scope of word of mouth: consumer-to-consumer information on the internet. In Valdosia, Susan, M. B., \& Kent, N. (Eds.), NA-Advances in consumer research, 4(2), 428-430.

Brasil chega a 76 milhões de usuários ativos no facebook (2013). Retrieved from http://tecnologia.terra.com.br/internet/brasil-chega-a-76-milhoes-de-usuarios-ativos-no-facebook,b9f019fd6 5870410VgnCLD2000000ec6eb0aRCRD.html

Brasil é o país onde o uso do facebook mais cresce (2013). Retrieved from http://tecnologia.terra.com.br/internet/brasil-e-o-pais-onde-o-uso-do-facebook-mais-cresce,4659f605102e04 10VgnCLD2000000dc6eb0aRCRD.html 
Brown, J. J., \& Reingen, P. H. (1987). Social ties and word-of-mouth referral behavior. J Consum Res, Gainesville, 14(3), 350-362. http://dx.doi.org/10.1086/209118

Butle, F. A. (1998) Word of mouth: understanding and managing referral marketing. Journal of Strategic Marketing, 6(3), 241-254. http://dx.doi.org/10.1080/096525498346658

Camargos, I. C. F. V., \& Lopes, E. E. F. (2013). Rede social não é SAC: as reclamações no facebook podem causar danos à imagem corporativa. In Congresso de Ciências da Comunicação na Região Sudeste, Bauru. Intercom - Sociedade Brasileira de Estudos Interdisciplinares da Comunicação.

Campbell, D. T., \& Stanley, G. C. (1979). Delineamentos experimentais e quase experimentais de pesquisa. São Paulo.

Cartola. (2013). Universitários latino americanos usam redes sociais com mais frequência. Retrieved from http://noticias.terra.com.br/educacao/universitarios-latino-americanos-usam-redes-sociais-com-mais-freque ncia,9e0c06f6fa1fe310VgnVCM4000009bcceb0aRCRD.html

Chetochine, G. (2006). Buzz marketing: sua marca na boca do cliente. São Paulo: Financial Times - Prentice Hall.

Choo, C. W. (2003). A organização do conhecimento: como ficamos sabendo - um modelo de uso da informação. São Paulo: $\quad$ SENAC. $\quad$ Retrieved from http://ufmggei2013.files.wordpress.com/2013/09/choo-chun-wei-a-organizac3a7c3a3o-do-conhecimento.pd $\mathrm{f}$

Churchill, G. A. (1999). Marketing research: methodological foundations (7th ed.). Chicago: The Dryden Press.

Churchill, G. A., \& Peter, J. P. (2003). Marketing: criando valor para o cliente. Cecília Camargo Bartalotti e Cid Knipel Moreira, São Paulo: Saraiva.

Cnt/Mda. (2013). O facebook é a rede social mais utilizada no Brasil. Retrieved from http://tecnologia.terra.com.br/internet/pesquisa-facebook-e-a-rede-social-mais-utilizada-no-brasil,5256aaa4 50def310VgnVCM4000009bcceb0aRCRD.html

Cross, R., \& Thomas, R. J. (2009). Redes sociais. São Paulo: Editora Gente.

Dados estatísticas e projeções atuais sobre a internet no Brasil. (2013). Retrieved from http://tobeguarany.com/internet-no-brasil/

Daquino, F. (2014). A história das redes sociais: como tudo começou. Retrieved from http://www.tecmundo.com.br/redes-sociais/33036-a-historia-das-redes-sociais-como-tudo-comecou.htm\#ix zz2q5WQm9n8

Duhan, D., et al. (1997). Influences on consumer use of word-of-mouth recommendation sources. Journal of the Academy of Marketing Science, 25(4), 283-295. http://dx.doi.org/10.1177/0092070397254001

Dyer, R. (2000). The buzz on buzz. Harv Bus Rev, 78(6), 139-146.

Engel, J. F., Miniard, P., \& Blackwell, R. D. (2005) Comportamento do consumidor (9th ed.). São Paulo: Thomson.

$\begin{array}{lllll}\text { Facebook. } & \text { (2014). } & \text { Annual } & \text { report } & \text { Retrieved }\end{array}$ https://www.facebook.com/ORBISInternational/app_538880569498840

Ferreira, F. C. (2011). O comportamento de procura de informação no processo de decisão de compra. Perspectivas em Gestão \& Conhecimento, 1(3), 3-26.

Freitas, H. (2000). Método de Pesquisa Survey. Revista de Administração, 35(3), 105-112.

Gil, A. C. (1999). Métodos e técnicas de pesquisa social (5th ed.). São Paulo: Atlas.

Gil, A. C. (2010). Como elaborar projetos de pesquisa (5th ed.). São Paulo: Atlas.

Godin, S. (2000). Unleashing the ideavirus. New York: Do You Zoom, Inc.

Gresolle, R. T. (2008). G. Consumir: desejo ou necessidade. 33 f. Caderno Pedagógico - Universidade Federal do Paraná, Curitiba.

Grewal, D., \& Levy. (2011). M. Marketing (3rd ed.). New York: McGraw-Hill/Irwin.

Hair, J., et al. (1995). Multivariate data analysis (4th ed.). Englewood Cliffs: Prentice Hall.

Haynes, S. N., Richard, D. C. S., \& Kubany, E. S. (1995). Content validity in psychological assessment: a 
functional approach to concepts and methods. Psychol Assess, 7(3), $238-247$. http://dx.doi.org/10.1037/1040-3590.7.3.238

Ibope Media. (2014). Número de pessoas com acesso à internet no Brasil chega a 105 milhões. Retrieved from http://www.ibope.com.br/pt-br/relacionamento/imprensa/releases/Paginas/Numero-de-pessoas-com-acessoa-internet-no-Brasil-chega-a-105-milhoes.aspx

Ikeda, A. A. (1997). Estratégias de promoção em serviços: a importância da comunicação boca a boca. In Encontro Anual da Associação Nacional de Pós-Graduação em Administração - ENANPAD, 21, Brasília.

Jenkins, H. (2009). Cultura da convergência (2nd ed.). São Paulo: Aleph.

Jesus, A. (2014). História das redes sociais: do tímido ClassMates até o boom do Facebook. Retrieved from http://www.techtudo.com.br/artigos/noticia/2012/07/historia-das-redes-sociais.html

Kinnear, T. C., Bernhardt, K. L., \& Krentler, K. A. (1995). Principles of marketing. Glenview: Foresman and Company.

Kotler, P. (1998). Administração de marketing: análise, planejamento, implementação e controle (5th ed.). São Paulo: Atlas.

Kotler, P., Kartajaya, H., \& Setiawan, I. (2010). Marketing 3.0: as forças que estão definindo o novo marketing centrado no ser humano. Rio de Janeiro: Elsevier Editora Ltda. http://dx.doi.org/10.1002/9781118257883

Kotler, P., \& Keller, K. L. (2006). Administração de marketing (12th ed.). São Paulo: Pearson Prentice Hall.

Kozinets, R. V. (1998). On netnography: initial reflections on consumer research investigations of cyberculture. Advances in Consumer Research, 25(12), 366-371.

Lemos, A. (2002). Aspectos da Cibercultura: vida social nas redes telemáticas. In Prado, José Luiz Aidar (Ed.), Crítica das práticas midiáticas: da sociedade de massa às ciberculturas. São Paulo: Hacker Editores.

Levy, M., \& Grewal, D. H. R. U. V. (2012). Marketing: integrando a ética em estratégias de publicidade e precificação (2nd ed.). Porto Alegre: Mcgraw Hill-Artmed.

Lira, W. S. (2007). Processo de decisão do uso da informação. Perspectivas em Ciência da Informação. Belo Horizonte, 12(2), 64-80. http://dx.doi.org/10.1590/S1413-99362007000200005

Malhotra, N. K. (2011). Pesquisa de marketing: uma orientação aplicada (3rd ed.). Porto Alegre: Artmed Editora S. A.

Marchiori, M., \& Oliveira, I. (2012). Redes sociais, comunicação, organizações. São Paulo: Difusão Paulista Editora.

Marconi, M. A., \& Lakatos, E. M. (2010). Fundamentos da metodologia científica (7th ed.). São Paulo: Atlas.

Maricato, P. (2005). Marketing para bares e restaurantes. Rio de Janeiro: Senac Nacional.

Marshall, L. (2003). O jornalismo na era da publicidade. São Paulo: Summus Editorial.

Mattos, A. (2011). Marketing digital: o que são redes sociais. Retrieved from http://administradores.com.br/artigos/marketing_digital_o_que_são_redes_sociais_artigo_de_alexandre_de _mattos_consultor_em_marketing_digital_/31442/

Miles, E. (1993). Adventures in the postmodernist kitchen: the cuisine of Wolfgang Puck. J Pop Cult, 27(3), 191-203. http://dx.doi.org/10.1111/j.0022-3840.1993.00191.x

Neto, G. (2013). Redes sociais são responsáveis por $62 \%$ do tráfego na internet. Retrieved from http://wwwmundodomarketing.com.br/10,11077

Oliveira, N. (2011). A história das redes sociais. Retrieved from https://www.natanaeloliveira.com.br/a-historia-das-redes-sociais/

Parasuraman, A. (2007). Marketing research (2nd ed.). Boston: Houghton Mifflin Harcourt Publishing Company.

Perrien, J., Cheron, E. J., \& Zins, M. (1983). Recherche en marketing: méthodes et decision. Boucherville: Gaëtan Morin éditeur.

Phelps, J. E. (2004). Viral marketing or electronic word-of-mouth advertising: examining consumer responses and motivations to pass along email. J Advert Res, 44(4), 333-348.

Richers, R. (1984). O enigmático mais indispensável consumidor: teoria e prática. Revista de Administração, São Paulo, 19(3), 46-56. 
Rosen, E. (2001). Marketing boca a boca: como fazer com que os clientes falem de sua empresa, seus produtos e serviços. São Paulo: Futura.

Salzman, M., Matathia, I., \& O'reilly, A. (2003). A era do marketing viral: como aumentar o poder da influência e criar demanda (11th ed.). São Paulo: Cultrix.

Santos, N. O. (2011). O twitter como ferramenta de marketing para gerar relacionamento e promover vendas. 78 f. Monografia de Conclusão de Curso (Graduação em Publicidade e Propaganda) - Faculdade Cearense, Centro de Ensino Superior do Ceará.

Schiffman, L. G., \& Kanuk, L. L. (2000). Comportamento do consumidor (6th ed.). Rio de Janeiro: Editora LTC.

Senecal, S., Kallczynski, P. J., \& Nantel, J. (2005). Consumers' decision-making process and their online shopping behavior: A clickstream analysis. $J$ Bus Res, Athens. http://dx.doi.org/10.1016/j.jbusres.2004.06.003

Sernovitz, A. (2012). Marketing boca a boca: como as empresas inteligentes levam as pessoas a falar delas (9th ed.). São Paulo: Cultrix.

Seybold, P. B. (2002). A revolução do cliente. São Paulo: Makron Books.

Silverman, G. (2001). The Secrets of Word-of-mouth Marketing: How to Trigger Exponential Sales Through Runaway Word of Mouth. New York: AMACON.

Sloan, D. (2005). Gastronomia, restaurantes e comportamento do consumidor. Baurueri: Manole.

Solomon, M. R. (2011). O comportamento do consumidor: comprando, possuindo e sendo (9th ed.). Porto Alegre: Bookman.

Stora, J. C. L. (1996). O cliente, capital da empresa. Barueri: NBL Editora.

Sussan, F., Gold, S., \& Weisfeld-Spolter, S. (2006). Location, Location, Location: the relative roles of virtual location, online word-of-mouth (eWOM) and advertising in the new-product adoption process. Adv Consum Res, 33(1), 649-650.

Taylor, S. J., \& Bogdan, R. (2000). Introduccion a los métodos cualitativos de investigación (3rd ed.). Barcelona: Ediciones Paidós.

Torres, C. (2009). A Bíblia do marketing digital. São Paulo: Novatec.

Triviños, A. N. S. (1987). Introdução à pesquisa em ciências sociais: a pesquisa qualitativa em educação: o positivismo, a fenomenologia, o Marxismo (4th ed.). São Paulo: Atlas.

Vannozi, M., \& Bridgestock, L. (2014). Students online usage. Global market trends reports. Retrieved from http://www.topuniversities.com/sites/qs.topuni/files/Students-Online-Useage-Global-Trends-Report-2013-n c.pdf

Wojnicki, A. C. (2006). Word-of-Mouth and Word-of-Web: talking about products, talking about me. Adv Consum Res., 33(3), 573.

Wolf, M. (2003). Teorias das comunicação (8th ed.). Lisboa: Editora Presença.

Womma (Word of Mouth Marketing Association). (2004). Wommapedia. WOMMA. Retrieved from http://www.womma.org/

\section{Note}

Note 1. Amazon.com (NASDAQ: AMZN) is a multinational electronic commerce company with U.S. headquarters in Seattle, Washington. It was one of the first companies with some relevance to sell products on the Internet. Amazon also includes Alexa Internet, a9.com, and the Internet Movie Database (IMDb).

\section{Copyrights}

Copyright for this article is retained by the author(s), with first publication rights granted to the journal.

This is an open-access article distributed under the terms and conditions of the Creative Commons Attribution license (http://creativecommons.org/licenses/by/3.0/). 